\title{
Globalisation, Southern Europe and European Adult Education Policy
}

\author{
CARMEL BORG \& PETER MAYO ${ }^{[1]}$ \\ Faculty of Education, University of Malta
}

\begin{abstract}
In this article, the authors define some of the most evident features of globalisation from below, which they distinguish from hegemonic globalisation, and draw out its implications for adult education. They draw out the implications for European adult education that emerge from the different features of these two types of globalisations. They then refer to the history of and contemporary provision in adult education in southern Europe and argue that there are elements there that can serve the purpose of a revitalised counter-hegemonic adult education approach. They then explore whether this thinking makes its presence felt in two major European documents, the EU Memorandum on Lifelong Learning and a recent report on adult education, carried out for the European Commission, provided by the European Association for the Education of Adults. They do this given that the international literature on adult education is dominated by ideas and experiences emerging from the central European states and Nordic countries. They highlight the recurrence in the Memorandum of the tendency to vocationalise adult education at different stages of a person's life. They consider the EAEA report to be more expansive and representative than the Memorandum but they also argue that there is a tendency to uncritically accept the vocationalisation of older adulthood. The issue of migration from south-of-the-equator populations to Europe, and especially southern Europe, is also considered, given that it is a prominent feature of the intensification of globalisation. Its implications for adult education practice are also considered, also and mainly in light of the situation obtaining in the frontier countries of southern Europe.
\end{abstract}

This article explores some of the impacts which the process of the intensification of globalisation is having on the adult education field in Europe. While the authors look at the European field in its larger context, they provide special emphasis on southern Europe for three reasons: (1) this is the region in which they live and operate as academics and practitioners in adult education; (2) it does not feature regularly in the English-language adult education literature; and (3) it is facing, because of its proximity to the shores of North Africa, a specific situation - massive immigration from North and sub-Saharan Africa - which, they argue, is relevant to and needs to be addressed in the adult education field.

\section{Two Types of Globalisation}

Globalisation is conceived of as an all-embracing concept, incorporating both its economic and its cultural dimensions, which are often inextricably intertwined, very much linked to the fact that, in the words of Manuel Castells (1999), 'we live in a global economy' (p. 54). This economy is one in which all processes work as a unit on real time throughout the planet; that is, an economy in which capital flows, labor markets, markets, the production process, management, information and technology operate simultaneously at the world level' (Castells, 1999, p. 54). 
In an interview with Roger Dale \& Susan Robertson (2004), Boaventura de Sousa Santos, echoing others (e.g. Marshall, 1997), identified two types of globalisation - hegemonic and counterhegemonic globalisation. The former is the type of globalisation predicated on the ideology of neoliberalism which, in his words, 'is the political form of globalization resulting from US type of capitalism, a type that bases competitiveness on technological innovation coupled with low levels of social protection' (Dale \& Robertson, 2004, p. 151). He goes on to state: 'The aggressive imposition of this model by the international financial institutions worldwide not only forces abrupt changes in the role of the state and in the rules of the game between the exploiter and the exploited ... but also changes the rules of the game among the other kinds of developed capitalism' (de Sousa Santos, in Dale \& Robertson, 2004, p. 151).

Counter-hegemonic 'globalization' (de Sousa Santos, in Dale \& Robertson, 2004, p. 150) or 'globalization from below' (Marshall, 1997) 'consists of resistance against hegemonic globalization organized (through local/global linkages) by movements, initiatives and NGO's, on behalf of classes, social groups and regions victimized by the unequal exchanges produced on a global scale by neoliberal globalization' (de Sousa Santos, in Dale \& Robertson, 2004, p. 150).

This second type of globalisation also comprises different movements, previously identified with a rather fragmentary identity and specific issue politics, coming together "on a scale previously unknown' (Rikowski, 2001, p. 16) to target global capitalism and the meetings of the institutions that support it, such as the International Monetary Fund (IMF), the World Bank and the World Trade Organization (WTO). But it also includes, as Carnoy (1999, p. 78) and others have indicated, movements who resist globalisation by asserting fundamentalist interpretations of their religious texts and other movements that seek to assert essentialist notions of identity in the face of threats, posed by globalisation, to these firmly entrenched notions. These notions include a 'fixed' sense of place, belonging and community. A number of exponents of what has come to be regarded as 'Militant Islam', as well as many fundamentalist Christians, would belong to the former category. Anti-immigrant movements would belong to the second category. Persons can belong to one or more of these categories.

All this has a bearing on adult education viewed in its broader context, as we will show in this article. Adult education is an amorphous field (Torres, 1987) and takes many forms, extending beyond institutionalised forms of learning and incorporating non-formal and informal learning. It also incorporates the learning activities taking place within social movements themselves, not all of which would prima facie be recognised as a learning activity. Administrative, mobilising and networking (including digital electronic networking) skills are, however, learnt in the process of carrying out such work. Work within movements also entails strategies to create wider public awareness of the matters at issue, and encourage commitment to the struggles involved. These strategies involve processes of education or mis-education (Chomsky, 2000), depending on one's point of view. It would now be appropriate to look at the two types of globalisation more closely, identify some of their features and relate them to the field of adult education, and specifically European adult education.

\section{Globalisation from Above}

Given the amount of literature that exists concerning neoliberalism and education (see, for instance, Pannu, 1996; Walters, 1997; Burbules and Torres, 2000; Dale and Robertson, 2004; Giroux, 2004; Olssen, 2004; Jarvis, 2006), it would be futile on our part to engage in an extensive discussion around this issue. We will highlight some of those aspects that, we feel, have a direct bearing on adult education.

The intensification of globalisation, occurring through massive breakthroughs in information and communication technologies, has led to an opening of borders and a liberalisation of services. The highly contested General Agreement on Trade in Services (GATS), currently being debated in the context of the WTO, would, if it goes through, have a bearing on all services within the context of education (de Siqueira, 2005; Hill \& associates, 2005, pp. 21-24; Verger \& Bonal, 2006).[2] Much of what would pass for adult education, especially that governed by the market and therefore run on commercial lines, would be seen as a service and would therefore be subject to GATS. 
Local entities engaging in this service already face stiff competition from foreign agencies operating in the field, many of which benefit from greater economies of scale. They even enter areas which have hitherto not been catered for by local agencies. Open universities, especially those using the hegemonic English language (see Macedo et al, 2003, on the importance of this language in a globalised context), as well as recognised British universities, have been very visible internationally in this area.

The opening of borders and multiple regional markets, a prominent feature of this process, has facilitated mobility of capital (fast-paced economic and financial exchange) and labour, though, as we shall argue, certainly not on a level playing field. This has led to the need for flexible workers and therefore the constant retooling of labour. Lifelong education, which was once promoted by UNESCO, but which had little impact on educational policy despite its having become part of the popular rhetoric, suddenly has been firmly placed on the international policy agenda, albeit with a modification to the terminology. The emphasis now is on 'learning' rather than 'education', a process that takes into consideration the various forms of learning engaged in by persons at all stages of their life. This, however, shifts the emphasis from the state, as a provider of services to which people are entitled, onto individuals, who must be responsible for their own learning. In the case of the European Union (EU), which has adopted this concept as its master-concept (to use the old UNESCO vocabulary), using the term 'learning' instead of 'education' also serves another purpose. Education is regarded within the $\mathrm{EU}$ as a matter of national sovereignty. Terms such as 'learning' and 'human resource development' become the choice words in these circumstances. The need to have flexible workers places the emphasis on learning and skills upgrading being not time-conditioned processes but constants throughout life, given the rapidity with which changes in the labour market are said to take place. Carnoy (1999) argues that globalisation has brought with it a perceived growth in demand for products with high level of skill, thus underlining the importance of skills upgrade through adult education and training (p. 15).

This leads countries to engage in spending on education for a more educated flexible and mobile workforce, in order to attract and maintain investment as well as remain competitive more generally in the global economy. There has been an expansion of higher education and this places pressure on universities and other higher education institutions to provide university continuing education services (see the various contributions to Osborne $\&$ Thomas, 2003). In countries not having the right infrastructure to cater for such an increase, including those which only recently established a public university, this could mean buying education services from outside.

Cyprus is one country, with the right infrastructure for higher education expansion, whose public university first opened its doors in 1992. The intake is limited. As a result, pressure is forthcoming from other sources, particularly private institutions, to open shop in Cyprus and, in cases such as the recently renamed University of Nicosia (formerly known as Intercollege) and Cyprus College [3], to be recognised as degree- and diploma-providing institutions. Malta, like Cyprus, a southern EU member state, is also witnessing pressure from private entities offering courses that are accessible to both full-time and part-time evening students and that are being provided by recognised UK universities such as those of Leicester, London and Sheffield Hallam, to name but three.

Other foreign bodies include the Geneva-based European University, which has branches in various countries, including Malta.

This occurrence is of great relevance to the issue of the impact of globalisation on university continuing education, especially with respect to established institutions where the 'concern for standards' and the workload of a limited, suitably qualified academic staff precludes them from offering highly sought-after degree courses in the evening. The monopoly of one institution, very much a characteristic of a very small state (and Europe has its share of very small states, including very small island states), is thus challenged. It is often encouraged by governments seeking to boost the country's graduate numbers to enable it to reach 'European levels'. These private institutions, often acting as mediators for recognised foreign bodies, alleviate the government's burden of having to finance the increase in public higher education. Market-driven university continuing education is seen to perform a useful role here. 


\section{Privatisation and Adult Education}

This situation is also symptomatic of another important feature of globalisation and its underlying neoliberal ideology: increasing privatisation (Hill \& associates, 2005, p. 6). This is in keeping with the ideology of the marketplace. Socially oriented adult education was a prime casualty in the shift from public to private sector bias as governments are under pressure to reduce growth of public spending on education. Adult education services are increasingly privatised according to the market, with more emphasis placed on human resource development (HRD) and information technology (IT). The familiar pressure faced by adult education organisers is to search for alternative sources of funding for socially oriented programmes. This often results in their resorting to European funding via the European Social Fund (ESF), but the emphasis is here placed on 'employability'. Applicants for European Social Funds often use their creative faculties to stretch the meaning of employability to introduce their own specific agendas into this setting.

While certain organisations in Europe, including those in southern Europe, can tap into limited funds from regional governments, the alternative might well be that they opt for a 'quick-fix' solution by turning to the corporate sector. Even here, the agenda would be compromised. The other solution is to join international partnerships involving counterparts from various regions of Europe and apply for funding under the Grundtvig action within what was until recently the Socrates Programme (now the Lifelong Learning Programme) or, if they can relate the area to training, what was previously the Leonardo Programme (now subsumed under the Lifelong Learning Programme). Furthermore, in the adult vocational sector, there is now an emphasis on co-funding, often involving employees and their representatives.

The widespread presence of and emphasis on information and communication technologies in adult education brings distance and online learning to the fore. As platforms become more versatile and supportive of rich visual and auditory interactions, and faster and more easy to use, we witness the facilitation of the liberalisation and provision of services coming from external centres, including those of former colonial powers. These foreign agencies and their representatives challenge the monopoly of local institutions and fill the gaps not provided by them. The global adult education centre can 'teach' adults anywhere and across time zones.

The area of social purpose adult education is, by and large, the most adversely affected as far as state funding is concerned. And the irony is that, while state funding is decreasing, the onus for such programmes, already placed on individuals, who are constantly called upon to take charge of their own learning, is also being shifted onto non-governmental organisations (NGOs) and community organisations. These organisations are entrusted with the task of helping to build a community's 'social capital'. This term, as employed by James Coleman (1988) and Robert Putnam (2000), is increasingly being used in the adult education discourse. The community organisations are exhorted to enable persons to become more 'entrepreneurial', personally, socially and economically, and less collective and dependent on the state. The debate on rights and responsibilities is rationalised and marketised, with 'autonomous choice' and 'self-help' being advocated for all.[4]

For the state has undergone a transformation of its previous role in reconciling the requirements of capital accumulation with the need to legitimate itself socially and democratically by addressing the demands for social programmes in a variety of social fields. The accumulation/legitimation function that was a characteristic of the state as it was once known (see Baran \& Sweezy, 1966; Carnoy \& Levin, 1985; Ross \& Trachte, 1990) gives way to a new set of functions that are characteristic of the neoliberal state. These include a non-interventionist approach and measures that contribute to the efficiency of the market, such as providing the infrastructure for investment and the mobility of capital, as well as the development of human resources'. While advocating for the liberty of the individual, the neoliberal state engages in policing borders and internal areas to control those who fall victim to the ruthlessness of the market - those who become, in Zygmunt Bauman's words, 'the human waste disposal' sector (Bauman, 2006). The image projected by the USA in this regard is that of being very much a 'carceral state', to use the term adapted by Giroux (2004) from Foucault's notion of a 'carceral society'. Perhaps an important function for adult education in this context would be that of stepping up education inside prisons - an area which is increasingly being given importance throughout Europe, and for which EU funding has also been provided - and in 'detention centres' 
for migrants who reach the shores of Europe. These centres, as has been reported with respect to places such as Malta [5] and Lampedusa (Sicily) [6], have often been denounced for the appalling conditions in which the detainees find themselves. We would consider them to be yet another manifestation of the 'carceral state'.

\section{Old Age as a Market}

One sector whose security has been jeopardised by this turn of events with respect to the State is that of older adults; we have an ageing population and a decreasing birth rate throughout Europe. The rise of this sector of the population has rendered it an important target for social-oriented adult learning, with NGOs, including those tied to various denominational churches in Europe, playing an important part in this context.

Neoliberal policies and the great demographic shifts that have occurred have led the neoliberal, post-welfare state to consider pensions unsustainable. Suddenly older adults are being regarded as important prospective members of the labour force. The retirement age for certain occupations is being raised and we often come across seminars discussing the feasibility of older adults being gainfully employed past the conventional retirement age. The discourse about adult education for the elderly has shifted from one that focused on non-instrumental learning, including the middleclass-oriented Universities of the Third Age (Formosa, 2000, 2007), the Elderhostels and the more popular community groups, to one that is increasingly becoming vocationalised. It is argued that older adults have much to offer the economy, as long as their labour skills are retooled. As a result, it is further argued, they would no longer be a burden on the state or, we would add, fall prey to the market which is now rendering pensions an individual rather than a social concern.

\section{Adult Education and Performance Indicator}

One other feature of globalisation and its impact on education is the emphasis on international quality comparisons - performance indicators, internal and external auditing, accreditation, standardisation, league tables, equivalences and harmonisation. While in the area of marketable skills, 'objective' measurability and comparability are perceived as achievable tasks, these are difficult to achieve in an area where a lot of non-formal and informal learning takes place. Attempts in this regard have, however, been made through the EU's provision of lifelong learning quality indicators and various projects funded by the EU concentrating on classification of competences for adult educators.

\section{Counter-hegemonic Globalisation}

Many consider the more progressive side of adult education to emerge within the context of counter-hegemonic globalisation. And there are those who pin their faith on social movements, given their disenchantment with leftist parties engaging in such action. Progressive social movements, from various parts of the globe, have made their mark in adult education. Apart from numerous NGOs, the anti-global movement that made its presence felt in Seattle, Davos, Genoa and elsewhere has provided a context for the understanding of issues related to international trade and global capitalism in its wider context.

Teach-ins, poster sessions, websites and print literature feature among the pedagogical strategies devised for this purpose. Ongoing developments in information and communication technologies challenge the hegemonic institutions' monopoly of knowledge. NGOs do not need expensive capital investments to relay their messages and engage in education processes.

Social movements such as the Frente Zapatista in Chiapas, who make great use of the web as part of their 'Internet war', and the landless peasant movement (MST) in Brazil have also made forms of popular education part of their work. The MST allies political activism and mobilisation with important cultural work, including highly inspiring music and poetry. The MST's extensive educational programme includes courses carried out within the various landless peasants' encampments (Kane, 2001, pp. 40-43) and the movement draws its inspiration from some of the revolutionary figures in Latin America, including Guevara and Freire. This movement has led to 
support groups emerging in Europe, groups such as the Comitato di Appoggio di Roma al MST (Committee of Support for the MST, Rome), which has produced a variety of resources that shed light on the movement and its concerns (e.g. Stédile \& Fernandes, 2001).

\section{Feminism and Counter-hegemonic Adult Education}

The adult education literature also abounds with articles and books relating to the counterhegemonic adult education provided within the context of feminism (Thompson, 1983, 1988; Miles, 1998; Hart, 1992; Darmanin, 1997), environmentalism (Hart, 1992; O’Sullivan, 1999; Clover et al, 2000), peace activism (Kekkonen, 1995) and citizenship movements such as that involved in the 'participatory budget' in Porto Alegre, Brazil (Schugurensky, 2002; Baerle, in Borg \& Mayo, 2007), to name but a few fields.

\section{The Learning Dimension}

Social movements have a learning dimension to their work (Welton, 1993; Hall \& Clover, 2006) and often incorporate adult education projects. However, many activists involved in social movement learning stress that for such learning to be effective it has to be linked with concerns that extend beyond the particular issue highlighted by a specific social movement. Environmentalist Vincent Caruana (in Borg \& Mayo, 2007) elaborates:

To be more effective (critical) Environmental Education needs to interact and dialogue more with the other so called 'adjectival educations' such as citizenship education, development education and peace education. In other words it needs to actively search for the ecological dimension to citizenship issues, social justice issues and peace issues and raise them as part of the struggle. The current boycott of Coca Cola (www.killercoke.org) is in protest of Coke's murder of indigenous working class organisers in Colombia but there is also an ecological dimension to this struggle - Coke's support for the mass-herbicide poisoning of the entire countryside with Monsanto's Round Up. The current boycott regarding produce from Israel and illegal Israeli settlements in the West Bank and Gaza is about ending the military occupation of Gaza and the West Bank but there is also an ecological dimension to this struggle - the poisonous cloud of pollution (containing high levels of poisonous lead, mercury and PCBs) spread over a third of Lebanon (an area that is home to half its people) from a fire in a bombed fuel tank that burned for 12 days. The same bombing released about four million gallons of oil into the sea, in the largest ever spill in the eastern Mediterranean. The unprecedented response of concerned citizens to the Tsunami disaster is about reconstruction but it is also about re-thinking coastal zone management and respecting the laws of nature. (p. 155)

\section{Regional Social Fora}

One context which allows possibilities for movements to reach out to and act in concert with others is the World Social Forum [7] and its related regional social fora. These fora bring movements together to consolidate the view that 'another world is possible' (see Fisher \& Ponniah, 2002). The first Mediterranean social forum [8], which took place in June 2005, brought women's organisations from various parts of the region together to participate in a Women's Assembly [9] which offers scope for networking and adult learning occurring on a broad international, if regional, scale.

\section{Technology as Liberatory Practice}

'Globalisation from below' also involves the use of technology for counter-hegemonic ends. While a lot of commercially and credentials-driven distance education focuses on areas such as business administration, training, professional courses and IT, we come across learning zones in the humanities, through blogs, on a whole range of subjects, including philosophy [10], which do not 
result in credits being awarded but which serve a non-utilitarian educational purpose. They provide a welcome respite from the excessive vocationalism that dominates the neoliberal educational scene. This is to be seen as a learning space. Progressive movements use the Internet, and IT more generally, for transformative ends, and their websites have a strong educational dimension. The Internet is one of the means that serves the interest of what has been termed a 'global civil society'.

If one were to eschew the current meaning attached to the term 'civil society' and adopt the meaning provided by Antonio Gramsci, then a global civil society relates to both forms of globalisation since it constitutes the terrain wherein a lot of the global domination, via global cable networks, information technology, and so on occurs. Once again, however, it creates spaces for counter-hegemonic action in that it offers the means for progressive groups, located in various parts of the world, to connect electronically or otherwise. IT is a double-edged sword in that, as an instrument of capitalism, it can constitute an effective process of domination, but can also offer counter-hegemonic possibilities in the fostering of international alliances (Hall, 1993). It can, however, also serve a counter-hegemonic purpose for conservative ends since civil society, in both the Gramscian and contemporary uses of the term, is not to be romanticised. As we have shown earlier, it comprises a whole range of groups and movements, including racists and religious fundamentalists.

\section{Adult Education in Southern Europe and Counter-hegemonic Globalisation}

\section{Inspirational Figures and Grass-Roots Democracy}

Several movements mentioned above derive their nourishment from various inspirational figures either through the latter's having served as role models, or because of their activism, or by means of their writings. Prominent among these figures is the Sardinian political leader, activist and theorist Antonio Gramsci, who has a particular following among social movements across the Atlantic and especially in Latin America. In their overview of adult learning within social movements, Hall \& Clover (2006) identify him, along with a host of others, as a source of inspiration. Gramsci hails from southern Europe, which is given scant exposure in the international adult education literature in the English language. And yet we would argue that this region furnishes us with a number of experiences, movements and personalities capable of inspiring different forms of counter-hegemonic adult education. We can point to the Mondragon experience, one of the better-known experiences from the region, with its emphasis on industrial democracy which, together with other attempts in industrial democracy from the region - namely, the Factory Council experience in Turin and the self-management strategies in the old Yugoslavia (then considered a Mediterranean country) - provide interesting contrasts to the fetish of workermanagement teams within the context of Total Quality Management. Another well-known development from southern Europe is the so-called 150 hours experiment in working-class adult education, where the unions attained the right to paid educational leave not for vocational purposes but for a general education (Yarnit, 1980).

We come across an experience of grassroots democracy ('omnicrazia') learning in Italy through the various post-war social orientation centres (Centro di Orientamento Sociale - COS) inspired by the anti-Fascist, Gandhi-inspired peace activist, Aldo Capitini (1899-1968) (Telleri, 2003, p. 97). The Centre for Social Orientation (COS), which Capitini founded in 1944 in his native Perugia, soon after the city's liberation, led to other centres emerging in such towns and cities as Ferrara and small localities in Umbria (Associazione Amici di Aldo Capitini, n.d.). It provided an education intended to empower people to hold those in power accountable and to engage in a form of deliberative democracy. The same can be said of the work of the internationally renowned Danilo Dolci (1924-1997) in Sicily who led by example, giving rise to 'non-violent' collective mobilisation and learning for change (including the so-called sciopero alla rovescia - upside-down strike) through such actions on his part as, for instance, hunger strikes (Barone, 2004; Castiglione, 2004). The other important figure whose pedagogical ideas can inspire and sustain counter-hegemonic work in neoliberal times is the Tuscan radical educator Don Lorenzo Milani (1921-1967). Lorenzo Milani will mostly be remembered for his work with school dropouts at Barbiana. He was, however, also involved in adult and youth education at San Donato di Calenzano (Simeone, 1996). One of the main emphases in his work, both at San Donato and at Barbiana, is on the collective 
dimension of learning. This stands in marked contrast to the current neoliberal maxim of individualisation that serves to project persons in two-dimensional terms: producers and consumers. Milani wrote and taught incessantly against the perils of spiralling consumerism, since he was active as an educator during the time of economic boom in Italy.

There are also elements of Latin American popular education which made their way into adult education provision in places such as Portugal and Spain. Apart from various forms of popular education, we notice adult education projects to prepare people in Seville for participation in a 'participatory budget' experiment (Lucio-Villegas Ramos, 2004; CIMAS, 2006; Florindo \& LucioVillegas Ramos, 2007) along the lines of the Porto Alegre experience. These elements of popular education could be the result of the cultural affinity existing between the Iberian and Latin American contexts. They are also slowly making their presence felt in Italy among social movements there, where they are combined with ideas and tools for community theatre deriving from Augusto Boal. The programmes involved, such as those of the Teatro Giolly, are social justice and community oriented. The Teatro Giolly engages in 'theatre of the oppressed' activities, such as 'forum theatre', where participants act as 'spect-actors' and engage in a process of consciousness raising intended to gain awareness of and confront oppressive structures (Roberto Mazzini, in Borg \& Mayo, 2007, p. 100).[11]

A participative form of adult education (see Puigvert, 2004) for social transformation and cultural renewal can be found in Spain. The efforts of CREC (Centre de Recursos I Educació Continua), in Xativa and Valencia, stand in marked contrast to the work of those providing a competence-based adult education, where the concern seems to be with what Lyotard calls 'performativity'(Wain, 2004). CREC, which is closely connected to the Paulo Freire Institute in Spain, focuses on providing resources for adult educators that centre on substantive wider issues rather than on narrow teaching techniques; there seems to be a preference for theoretical writings rather than 'mix-and-stir' teaching recipes. It provides adult educators with numerous books in Catalan, often translations of major social philosophical, sociological or adult education theoretical works that furnish the reader with a critical social perspective.

\section{Groups, Movements and Possibilities for Historical Blocs in Adult Education}

The example of CREC and others indicate that it is not only individuals but also groups and movements that ought to be mentioned with regard to adult education. The Mediterranean Review/Mediterraneo Un Mare di Donne, a bilingual periodical in Italian and English [12], provides visibility to women's groups and organisations from the region, that challenge patriarchy at different levels and in different areas. There are other Mediterranean organisations and networks that make women the focus of their attention, and we earlier mentioned the Women's Assembly at the first Mediterranean Social Forum (FSMED). These organisations constitute the basis for a women's movement in the Mediterranean which, once again, like all movements, has a learning dimension to its activities.

A question arises (Mayo, 1999): Is there room for an international progressive historical bloc characterised by an alliance and consensus among different movements and organisations? International fora such as those centring on the ideas of Paulo Freire (it is significant that the three of the five fora to date took place in southern European cities - namely, Bologna, Porto and Valencia) help bring different activists together so that ideas converge and potential joint projects are devised. Others use the Internet to publicise their ideas and those of the figures and movements who gave rise to them. Some, like the women's organisation Mediterraneo Un Mare di Done/Mediterranean Review, publish their material in both Italian and English, thus providing the conditions to reach out to other groups across the region. Others such as CREC (Centre de Recursos I Educació Contínua) or the Centro di Formazione e Ricerca Don Milani e Scuola di Barbiana [13] provide their material in their own native language, and it therefore has a very limited reach across their boundaries. The main challenge therefore remains that of bringing these forces and the thinking around them together for an international effort to confront the hegemonic form of adult education that pervades contemporary discourse and continues to render the kind of progressive and emancipatory traditions, to which the above movements belong, a repressed historical and contemporary alternative. 


\section{How Much of this is Incorporated into European Adult Education Policy?}

To what extent are elements from 'the counter-hegemonic form of globalisation' making their way into European adult education policy? It might be argued that once they become incorporated, these elements stop being counter-hegemonic. Furthermore, the mainstream system is often adept at incorporating elements of this alternative discourse to secure consent and therefore greater legitimacy as part of what Gramsci would call a 'war of position'. We now look at two European documents, the first of which, the EU Lifelong Learning Memorandum (henceforth EU LLM), is certainly a document intended to provide guidelines for policy-making in adult education and lifelong learning more generally in EU member states. The second document, produced by the European Association for the Education of Adults (EAEA), focuses on the different trends and issues in adult education throughout EU member states. It was commissioned by the EU. The latter is more of an advocacy document than a policy document. We dealt at length with the first document in a series of publications (see Borg \& Mayo, 2004, 2005, 2006; Walters et al, 2004). We will provide a synoptic critical commentary on the Memorandum's six key messages. These are: (a) new basic skills; (b) investment in human resources; (c) innovation in teaching and learning; (d) valuing learning; (e) guidance and information; and (f) bringing learning closer to home.

\section{Message 1: New basic skills for all}

The report published by Cedefop, Eurydice (2001) reveals a range of interpretations of the term 'basic skills'. However, it is becoming increasingly apparent that the dominant discourse on 'basic skills' is labour-market oriented. The net result of this orientation in curriculum reform is that '[a]rrangements for guidance, support and identification of skills needed by the labour market, in cooperation with the social partners, are highly significant aspects of curricular provision' (Cedefop/Eurydice, 2001, p. 15).

Missing from the Memorandum's section on 'basic skills' is the notion of what Freire and others would broadly term 'critical literacy', echoed also in Milani's (2002) insistence on critical readings of contemporary reality and its construction through the media. This attribute would render the discourse on new skills, in the Memorandum, less dominated by the ideology of competitive individualism. Also included in this message is the skill of being able to take charge of one's own learning. However, the notion of 'taking charge of one's own learning' is conceived of in simply individualistic terms that can result in placing the entire responsibility for learning on the individual, with the danger that failure to achieve can be blamed on the victim and not the State.

We reiterate the view that learning is a social act and yet we do not come across, in this message, the 'collectivity' dimension, the important dimension stressed by Freire, Milani and some of the movements from southern Europe to which reference was made earlier on. We should perhaps begin to speak in terms of self- and collectively directed learning.

\section{Key Message 2: Investment in human resources}

This message's objective is to '[v]isibly raise levels of investment in human resources in order to place priority on Europe's most important asset - its people' (Commission of the European Communities [CEC], 2000, p. 12). This section emphasises the need for a culture of shared responsibility for the education of present and prospective employees. This takes the form of individual incentives such as the opening of learning accounts, subsidised study leave and the affirmation of one's right to training opportunities. It also emphasises the need for more flexible working arrangements that allow employees to learn and upgrade their profile. Once again, the education of workers, in this section, is presented in a manner that suits the interests of the employer by rendering employees partly responsible for their professional upgrading and by relieving employers of part of the responsibility for the provision of training, making the other social partners share the burden. There is little in this section on the rights of employees and their representatives (important social partners) to negotiate paid educational leave for studies in areas which extend beyond the narrow focus of vocational preparation, in the way that, for instance, the steel-metal workers in Italy, through their union representatives, negotiated the right to 150 hours' paid educational leave for a general education (Yarnit, 1980). 
Key Message 3: Innovation in teaching and learning

This message's objective is to '[d]evelop effective teaching and learning methods and contexts for the continuum of lifelong and lifewide learning' (CEC, 2000, p. 13). The message calls for 'a major shift towards user-oriented learning systems with permeable boundaries across sectors and levels'. It refers to the need for 'individuals to become active learners', with the implication being that there is a need to improve existing practices and 'take advantage of the opportunities offered by ICT and by the full range of learning contexts' (CEC, 2000, p. 13). It adds that the ' 11$]$ earning systems must adapt to the changing ways in which people live and learn their lives today. This is especially important for achieving gender equality and catering to the increasingly active "Third Age" citizenry' (CEC, 2000, p. 14). It also places the emphasis on upgrading the skills of those engaged as educators in formal and non-formal learning environments, be they paid professionals, volunteers or those to whom teaching is a secondary function (CEC, 2000, p. 14).

Quite commendable is the sensitivity shown towards social difference based on the recognition of the way traditional teaching ignores such differences and reinforces normalising discourses regarding femininities, masculinities and age. There is an emphasis throughout this and other lifelong learning and lifelong education literature on the need for educators to serve as facilitators, resource persons and so on. While this no doubt results from dissatisfaction with traditional pedagogical methods that are alienating to various categories of students, one must guard against the danger of the pedagogical approach involved degenerating into laissez-faire pedagogy which inevitably favours those who enjoy greater access to resources or, worse, the transmission as 'facilitators' of pre-packaged learning material which the excessive use of IT facilitates.

The use of IT in education is naturally given prominence. E-networking is an important development that allows possibilities for collective learning, often with a social purpose, across the globe. On a less optimistic note, however, excessive use of IT in education can continue to render learning an isolated and individualistic activity.

\section{Key Message 4: Valuing learning}

Message 4's objective is to '[s]ignificantly improve the ways in which learning participation and outcomes are understood and appreciated, particularly non-formal and informal learning' (CEC, 2000, p. 15). The message stresses the need to address the current situation where it is stated that ' $[\mathrm{t}]$ he rising demand for qualified labour by employers and increased competition between individuals to gain and keep employment is leading to a much higher demand for recognised learning than ever before'.

One would have expected to find, in this section, the kind of broad philosophical discussion concerning the 'value of learning' reminiscent of the 'old' lifelong education literature. Kenneth Wain states in this regard:

Indeed the whole tenor of the section could send out the wrong message to governments, institutions, and individuals, that what is valued is only this kind of learning, vocational learning for the purposes of the economy and the job market. While it recognises the great importance of such learning, the committee feels that learning for other than vocational purposes should have been duly recognised and given space in the memorandum especially since the memorandum itself speaks of 'promoting active citizenship' as 'equally important.' [14]

\section{Key Message 5: Rethinking guidance and counselling}

The objective of Message 5 is to 'Ensure that everyone can easily access good quality information and advice about learning opportunities throughout Europe and throughout their lives' (CEC, 2000, p. 17). This message is of great importance for countries in Europe that still restrict guidance and counselling facilities to schools and tertiary institutions, as well as labour market public and private entities. Given the variegated and broad nature of the field of education, comprising the formal and non-formal sectors, not to mention informal learning, a holistic and lifelong approach to guidance and counselling is being advocated in European Commission documents (Sultana, 
2003). The net result of this strategy at the European level is that more and more guidance and counselling provisions are following citizens throughout life; enhancing social inclusion by engaging reluctant learners in educational and training experiences; presenting up-to-date information that responds to client and employer needs; networking with NGOs to address specific needs; and exploiting the potential of technology-based infrastructures for guidance and counselling purposes (Sultana, 2003). The Memorandum should be applauded for attaching importance to the development of such a service intended to be accessible in terms of cost, location and suitability for people of different ages, young and adult alike.

The emphasis on placing 'the client's interests in the forefront' (CEC, 2000, p. 17) is quite appropriate given the learner-centred approach that is continuously advocated in the context of lifelong learning. The Memorandum should also be applauded for warning against the danger of a market-based approach to this area: 'Over the past thirty years, market-based services have mushroomed, especially for the highly qualified. In some Member States, many guidance and counselling services are wholly or partially privatised' (CEC, 2000, p. 18). Rather than simply 'define entitlements' and 'set agreed minimum standards', the public sector should take it upon itself to increase provision in this vital area, quality provision accessible to one and all.

\section{Key Message 6: Bringing learning closer to home}

The objective of this message is that of providing lifelong learning opportunities as close to learners as possible, in their own communities and supported through ICT-based facilities wherever appropriate' (CEC, 2000, p. 19). This is a very interesting section of the Memorandum that again stresses the notion of outreach, which requires that one draws on the experience garnered in this area by organisations and educators involved in the related fields of community education, action and development, education in prisons, education of older adults and education of the disabled. The section deals with the use of IT in offering 'great potential for reaching scattered and isolated populations' (CEC, 2000, p. 19). It also deals with developing the idea of 'lifelong learning as the driver for local and regional regeneration' and the creation of 'appropriate kinds of learning centres in everyday locations where people gather' (CEC, 2000, p. 19).

As with the rest of the document, there is an over-emphasis on the use of IT which no doubt has its merits but, once again, if it is not used carefully and creatively, with educators and learners as important mediators and, better still, co-learners using IT equipment as a complementary resource, it can serve as the vehicle for the transmission of pre-packaged material.

The idea of having 'learning centres in everyday locations' is also to be commended since it is based on the recognition that learning takes place in a variety of settings, many of which constitute sites of much of what passes for 'lifewide education'. The Memorandum refers to lifelong learning as serving as the vehicle for local and regional regeneration. Initiatives connected with Key Message 6 allow scope for partnerships to develop among formal and non-formal, including grassroots, organisations. These partnerships would be justified on the grounds that some of the formal institutions, such as universities, are public institutions supported, for the most part, by public taxes, the taxes of those living within the region. To what extent would the efforts of the grassroots movements improve through greater access to the university's resources? Having said this, there are limits to the kind of regional regeneration and development that is possible in certain contexts, given that uneven levels of development are widely held to be endemic to the capitalist mode of production.

\section{Neoliberalism and a Market-Oriented Definition of Social Viability}

The Memorandum's messages ought to be read in a manner that recognises its underlying marketoriented definition of social viability. In general, although it stresses the need for an education connected with active democratic citizenship, underlines the importance of social difference, and is full of social democratic trappings, the Memorandum is found wanting in its analysis of the effects of neo-liberal, socio-economic policies on educational change. Therefore, while the document refers to 'community', 'citizenship' and 'solidarity', the content is, for the most part, framed by capitalism's latest re-organisational needs: flexibility, mobility, job-related counselling and basic 
employment-related skills. Rather than rupturing the process of the global auctioning of human services, the Memorandum reinforces the idea that closer links between education and the economy are inevitable.

\section{The EAEA's 'Trends and Issues in European Adult Education'}

Recently an EAEA-led consortium carried out the work, entitled 'Adult Education Trends and Issues in Europe.'[15] This 73-page study provides a wide-ranging analysis of the current situation concerning non-formal adult education throughout the continent. Recommendations for the future are formulated in this expansive study. The issues it covers range from immigration to old age, and the authors discuss such topics as funding, regional partnerships and intergenerational learning. The document can be truly inspirational for anyone seeking to influence the development of adult education in his/her own country, region or municipality. In EU member states, this is a very important current occurrence as governments engage in attempts to develop national lifelong learning strategies for which the EU LLM serves as an important source of reference. Particularly striking is the second part of the study concerning certain points made with respect to ageing, decentralisation, partnerships, finance and intergenerational learning. We winced when faced with the term 'human capital' and to a lesser extent 'social capital', since we feel these terms keep us trapped in the logic of capital accumulation. We are more concerned with the first of the two terms, that is unappreciative of the full range of subjectivities that characterise the adult learner. This point is made throughout the study itself, where much emphasis is placed on adult education that extends beyond the simply vocational. We have shown earlier how the term 'social capital' can accommodate neoliberal thinking and discourse. Furthermore, as some studies have shown, greater trust, affiliation and networking, some of the key indicators of 'social capital', can be exclusionary and lead to narrow as opposed to more general social interests.

We now dwell on two crucial issues given adequate importance in the report - the issues of immigration and ageing. These two issues must be central to any report mapping out trends and current issues in European Adult Education in the context of the intensification of globalisation. Many countries, especially those from southern Europe, have turned from being exporters to being net importers of migrants. These include Greece, Portugal, Italy (including southern Italy), Spain and Malta. Malta's case is worrying since we have a very small state which is a frontier state with regard to North Africa, from where a lot of migrants from sub-Saharan and north Africa cross over the new 'Rio Grande' that is the Mediterranean. The often-expressed fear in Malta is that the small island state, like its nearby Italian island of Lampedusa, will be 'swamped'. This generates xenophobia and racism (evident in many parts of Europe but writ large in these small island contexts under these circumstances), and so there is a need for anti racist adult education to be stepped up in these places and elsewhere, targeting all those engaged in work relating to immigration (e.g. immigration officers, journalists, army, police and so on). As elsewhere, this occurrence of massive immigration from North Africa has led to the emergence of ultra-right, neofascist movements, and, in Malta, violence is often perpetrated against immigrants and the property of those who write in favour of or support immigrants and the development of a multi-ethnic society. Anti-racist education should be stepped up across the whole gamut of educational provision in such places. There is also the need for detention centres, where immigrants are kept until a decision is made as to whether they should be granted refugee status or not, to be transformed into 'lifelong learning centres'. These centres would provide programmes in adult education for integration and also resettlement - resettlement into European countries. Small frontier EU member countries cannot tackle this massive immigration situation on their own and require support from other larger European countries that can accommodate migrants. These countries, or some of them, have a moral obligation towards migrants from Africa, having been responsible for the underdevelopment of Africa through their colonial policies in the past. This support can include the provision of material and resources for an adult education programme that involves the teaching of such areas as the language and culture of the country or countries where these immigrants can resettle (Borg \& Mayo, 2006).

The discussion on the ageing population, in this EAEA study, is enlightening and highlights one of the main issues facing adult education policy makers at present. The issue of pensions is a crucial 
one these days and it is one of the areas where social class politics seems to be coming back to the fore. We think the recommendations made in the document are plausible, as indeed there is a key role for adult education to play here. However, the current situation regarding the raising of the retirement age and the need to engage people over 60 in the labour force to counter the perceived non-sustainability of the current pension schemes can lead us to view the education of older adults only in economic terms. There is an urgent need for the provision of general adult education targeting the many old people's homes that are mushrooming everywhere in Europe. Adult education should constitute an important feature of activity in these homes that can serve to improve the quality of life of the residents and therefore make the prolongation of life desirable. There is a need for the preparation of a specialised cadre of adult educators who can provide meaningful educational experiences among older adults in these homes.

One other important element missing from this study is a concern with the development of adult education for planetary consciousness, a crucial issue in an age of the intensification of globalisation. There is a felt need for a wide-ranging educational strategy that confronts an ideology where money and profit (the bottom line) are the basic values that render the earth subject to abuse.

Biodiversity should be an important concern among adult and popular educators around Europe as we continue to live in a system in which the earth is subjected to rhythms it cannot withstand and the rest of the universe continues to be conceived of as an object of commodification in a predatory and plundering economic system with global tendencies. We need to conceive of active citizenship in terms of improving not only social relations but also human-earth relations. Fortunately there exist movements and organisations that promote this view of learning. Their work needs to be acknowledged and foregrounded.[16] Examples include the Mediterranean NGO Network for Ecology and Sustainable Development, and Greenpeace Mediterranean. Unless we learn to develop a biocentric world view by which we see ourselves as being rooted in rather than in control of nature, we will continue to witness ecological degradation. Mainstream European adult education needs to learn from the work of several NGOs active in transformative ecopedagogical action within the context of the Earth Charter. More efforts should be channelled in the direction of adult education programmes that not only serve to redistribute wealth but enable learners to redefine wealth itself (Milani, 2002) with a view to enhancing the quality of life on and with the rest of the cosmos. Alas, much of the neoliberal discourse that informs many of the documents concerning lifelong learning in Europe militates against this aspect of adult learning. It is a discourse that often promotes market-driven rather than life-centred values.

\section{Conclusion}

The hegemonic status of neoliberalism has brought about a shift in education policy and in the allocation of funds for education. This article illustrated how the privatisation of public services and the State's retreat from its welfare obligations are being reflected in a dominant, glocal discourse in adult education that privileges training for private production, competition and consumption. A sector, adult education, traditionally dominated by public institutions and NGOs, is undergoing a continuing process of privatisation, where balance is being shifted towards performativity, retooling and employability rather than social engagement and affirmative action.

In light of this scenario, and in full knowledge of the fact that hegemony is never complete, we provided various examples of local and global counter-hegemonic adult education to argue the case for the development of more adult learning spaces that are critical, public and socially committed. In the face of corporate mediation of social and human-earth relations, we believe that reclaiming adult education sites and policy as possibilities for social agency and critical citizenry should contribute to a moral imagination that transcends the commonsense, market-driven vision of citizens as subjects of consumption. And we feel that there is quite a repressed tradition in adult education, including wonderful and imaginative experiences deriving from southern Europe (alas given scant importance in Northist-dominated international adult education literature in English) that, as we have shown, can provide nourishment for those seeking to reclaim the social purpose of adult education and explore its possibilities for a really genuine social empowerment. 


\section{Notes}

[1] The authors would like to thank participants in the following classes taught by Peter Mayo for their insights that helped inform this article: the participants in the 2006 MA comparative course module on globalisation and education, EMCER, University of Malta; the participants in the anthropology 2006-2007 unit 'Globalisation and Racism', anthropology programme, Mediterranean Institute, University of Malta; and the participants in the 2007 seminar on 'Educazione e Mediterraneo. Cambiamenti e Nuove Sfide' dottorato di ricerca programme, University of Verona, Verona, Italy.

[2] See the November special issue of Globalisation, Societies and Education on GATS: 1(3).

[3] We are indebted to Professor Helen Phtiaka for this information.

[4] We are indebted to Professor Margaret Ledwith for this point.

[5] See the report by Matthew Vella, 'MEPs Appalled at Detention Centres', in MaltaToday, 26 March 2006. http: / / www.maltatoday.com.mt/2006/03/26/t15.html

[6] See the article by Fabrizio Gatti in L'Espresso reproduced at: http: / / www.metamorfosi.info/ infodetail.asp?categoryid=45 \&infoid=2525

See also the damning report on treatment of immigrants at the overcrowded Lampedusa detention centre (Centri di Permanenza Temporanea e Assistenza - Centres for Temporary Stay and Assistance) by Amnesty International Italia:

http: / / www.amnesty.it/pressroom/documenti/lampedusaue.html?page=documenti See also the article by Fabio Raimondi, 'Centri di Permanenza Temporanea' (Administrative Detention Centres) - the new borders of exploitation, with specific reference to the Bossi-Fini law concerning the detention of immigrants, on nolager.org: http: / / nolager.org/more/ display.php?id=14

[7] The World Social Forum is a contested terrain. For a critique of the WSF see, for example, 'World Social Forum Karachi: a left critique'

(http:/ / www.nadir.org/nadir/initiativ/agp/free/wsf/2006/karachi/0321left_critique.html); Flore-nne Bourgeois (2006), 'The World Social Forum at a Crossroads', Centre for Applied Studies in International Negotiations; and Anuradha Mittal (2007), 'VII World Social Forum' (http: / / www.ipsterraviva.net/tv/Nairobi/ en/viewstory.asp?idnews=778).

[8] See the Associazione Donne del Mediterraneo's website: http: / / www.donnedelmediterraneo.org/intro.php

[9] See the website: http: / www.fsmed.info/it/asmujeresfsmed-it.rtf

[10] See the following website containing a long list of philosophy blogs: http:/ / consc.net/weblogs.html Other websites including philosophy blogs include:

http:/ / www.philosophyblog.com.au/ http: / / experimentalphilosophy.typepad.com/

http: / / www-users.york.ac.uk/ twcs1/Blogger/philosophy.html http:/ / www.kristenandshawn.com/philblog/2006/07/ consumerism-in-education.html We are indebted to Joseph Vancell for this information.

[11] See http: / / www.giolli.it

[12] See http:/ / www.medmedia.org/review/index.htm, updated last on 30 November 2006.

[13] http:/ / www.icareancora.it/ (accessed 24 March 2007).

[14] Short paper on message 4 delivered by Kenneth Wain at the National Consultation Conference on Lifelong Learning held in Malta in May 2001.

[15] http:/ / www.eaea.org/doc/ eaea/AETIstudyfinal.doc

[16] See the following websites concerning fora for learning and action that exist in or are focused on Southern Europe and the Mediterranean: http: / / www.medforum.org/english/index.htm, http://www.mio-ecsde.org/ http:/ / www.foeme.org/

http: / / www.foeeurope.org/mednet/about.htm http://www.greenpeace.org/mediterranean/, http: / / www.euromedplatform.org/spip/index.php?lang=en. We are indebted to Vincent Caruana for this information. 


\section{References}

Associazione Amici di Aldo Capitini (n.d.) Introducing Aldo Capitini, DVD.

Baran, P. \& Sweezy, P (1966) Monopoly Capital. New York: Monthly Review Press.

Barone, G. (2004) La Forza della Nonviolenza. Bibliografia e profile bibliografico di Danilo Dolci. Naples: Dante $\&$ Descartes; Partenico: Centro per lo Sviluppo Creativo 'Danilo Dolci'.

Bauman, Z. (2006) The Crisis of the Human Waste Disposal Industry, in D. Macedo \& P. Gounari (Eds) The Globalization of Racism. Boulder: Paradigm.

Borg, C. \& Mayo, P. (2004) Diluted Wine in New Bottles: the key messages of the EU Memorandum (on Lifelong Learning), Lifelong Learning in Europe (LlinE), IX(1), 19-25.

Borg, C. \& Mayo, P. (2005) The EU Memorandum on Lifelong Learning: old wine in new bottles? Globalisation, Societies and Education, 3(2), 257-278. http: / / dx.doi.org/10.1080/14767720500167082

Borg, C. \& Mayo, P (2006) Learning and Social Difference: challenges for public education and critical pedagogy. Boulder: Paradigm.

Borg, C. \& Mayo, P. (2007) Public Intellectuals, Radical Democracy and Social Movements. New York: Peter Lang.

Burbules, N.C. \& Torres, C.A (Eds) (2000) Globalization and Education: critical perspectives. New York \& London: Routledge.

Carnoy, M. (1999) Globalization and Educational Reform: what planners need to know. Paris: UNESCO.

Carnoy, M. \& Levin, H (1985) Schooling and Work in the Democratic State. Stanford: Stanford University Press.

Castells, M. (1999) Flows, Networks and Identities: a critical theory of the information society, in M. Castells, R. Flecha. P. Freire, H. Giroux, D. Macedo \& P. Willis (Eds) Critical Education in the Information Age. Lanham: Rowman \& Littlefield.

Castiglione, A. (Director) (2004) Danilo Dolci: memory and utopia. Partencio: Centro per lo Sviluppo Creativo 'Danilo Dolci'. http:/ / www.danilodolci.net

Commission of the European Communities (CEC) (2000) Commission Staff Working Paper: a memorandum on lifelong learning. Brussels: European Commission.

Cedefop, Eurydice (2001) National Actions to Implement Lifelong Learning in Europe. Thessaloniki and Brussels: Cedefop/Eurydice.

Chomsky, N. (2000) Chomsky on MisEducation, ed. D. Macedo. Lanham: Rowman \& Littlefield.

CIMAS (Observatorio Inrternacional de Ciudadania y Medio Ambiente Sostenible) (2006) La Pedagogía de la Decisión. Aportaciones teóricas y prácticas a la construcción de las Democracias Participativas. Seville: Ayuntamiento de Sevilla (Delegación de Participación Ciudadana) \& CIMAS.

Clover, D., Follen, S. \& Hall, B. (2000) The Nature of Transformation: environmental adult education. Toronto: Department of Adult Education, Community Development and Counselling Psychology.

Coleman, J. (1988) Social Capital in the Creation of Human Capital, American Journal of Sociology, 94, 95-120. http:// dx.doi.org/10.1086/228943

Dale, R. \& Robertson, S. (2004) Interview with Boaventura de Sousa Santos, Globalization, Societies and Education, 2(2), 147-160. http:/ / dx.doi.org/10.1080/14767720410001733629

Darmanin, M. (1997) Women's Studies in Adult Education, in G. Baldacchino \& P. Mayo (Eds) Beyond Schooling: adult education in Malta. Malta: Mireva.

de Siqueira, A.C. (2005) The Regulation of Education through the WTO/GATS, Journal for Critical Education Policy Studies, 3(1). http:/ / www.jceps.com/?pageID=article\&articleID=41.

Fisher, W.F. \& Ponniah, T. (Eds) (2002) Another World is Possible: popular alternatives to globalization at the World Social Forum. London: Zed Books.

Florindo, A.G. \& Lucio-Villegas Ramos, E (2007) Presentation of material at Presupuestos Participativos, Educación Ciudadana y Movimentos Sociales seminar, Facultad de Ciencias del Trabajo y E.U. Trabajo Social, University of Huelva (El Carmen Campus), 7 May, Huelva, Spain.

Formosa, M. (2000) Older Adult Education in a Maltese University of the Third Age: a critical perspective, Education and Ageing, 15(3), 315-339.

Formosa, M. (2007) A Bourdieusian Interpretation of a University of the Third Age in Malta, Journal of Maltese Education Research, 4(2), 1-16.

Giroux, H.A. (2004) The Terror of Neoliberalism: authoritarianism and the eclipse of democracy. Boulder: Paradigm.

Hall, B.L. (1993) Learning and Global Civil Society: electronic networking in international non-governmental organisations, International Journal of Computers in Adult Education and Training, 3(3), 5-24. 
Hall, B.L. \& Clover, D. (2006) Social Movement Learning, in R. Veira de Castro, A.V. Sancho \& P. Guimarães (Eds) Adult Education: new routes in a new landscape. Braga: University of Minho.

Hart, M. (1992) Working and Educating for Life: feminist and international perspectives on adult education. London \& New York: Routledge.

Hill, D. \& associates (2005) Education Services Liberalisation, in E. Rosskam (Ed.) Winners or Losers? Liberalizing Public Services. Geneva: International Labour Office.

Jarvis, P. (2006) Globalisation, Knowledge and Lifelong Learning, in R. Veira de Castro, A.V. Sancho \& P. Guimarães (Eds) Adult Education: new routes in a new landscape. Braga: University of Minho.

Kane, L. (2001) Popular Education and Social Change in Latin America. London: Latin American Bureau.

Kekkonen, H. (1995) Adult Education for Peace, in B. Cassandra (Ed.) Adult Education through World Collaboration. Melbourne, FL: Krieger.

Lucio-Villegas Ramos, E. (2004) Tejiendo la Ciudadania Desde la Educación, in E. Lucio-Villegas Ramos \& P. Aparicio Guadas (Eds) Educación, democracia y emancipación. Xativa: Dialogos.

Macedo, D., Dendrinos, B. \& Gounari, P. (2003) The Hegemony of English. Boulder: Paradigm.

Marshall, J. (1997) Globalization from Below: the trade union connections, in S. Walters (Ed.) Globalization, Adult Education and Training: impacts and issues. London: Zed Books.

Mayo, P. (1999) Gramsci, Freire and Adult Education: possibilities for transformative action. London: Zed Books.

Milani, B (2002) From Opposition to Alternatives: postindustrial potentials and transformative learning, in E. O’Sullivan, A. Morrell \& M.A. O’Connor (Eds) Expanding the Boundaries of Transformative Learning: essays on theory and praxis, 47-58. New York \& Basingstoke: Palgrave.

Miles, A. (1998) Learning from the Women's Movement in the Neo-Liberal Period, in S.M. Scott, B. Spencer \& A. Thomas (Eds) Learning for Life: Canadian readings in adult education, 250-258. Toronto: Thompson Educational Publishing.

Olssen, M. (2004) Neoliberalism, Globalization, Democracy: challenges for education, Globalization, Societies and Education, 2(2), 231-276. http:/ / dx.doi.org/10.1080/14767720410001733665

Osborne, M. \& Thomas, E.J. (Eds) (2003) Lifelong Learning in a Changing Continent: continuing education in the universities of Europe. Leicester: National Institute of Adult Continuing Education (NIACE).

O’Sullivan, E. (1999) Transformative Learning: education for the 21st century. London \& New York: Zed Books; Toronto: University of Toronto Press.

Pannu, R.S. (1996) Neoliberal Project of Globalization: prospects for democratisation of education, Alberta Journal of Educational Research, XLII(2), 87-101.

Puigvert, L. (2004) North-South/South-North Relations in Adult Education, in D. Caruana \& P. Mayo (Eds) Perspectives on Lifelong Learning in the Mediterranean. Bonn: IIZ-DVV.

Putnam, R.D. (2000) Bowling Alone: the collapse and revival of American community. New York: Simon \& Schuster.

Rikowski, G. (2001) The Battle in Seattle: its significance for education. London: Tufnell Press.

Ross, R. \& Trachte, K.C. (1990) Global Capitalism - the new leviathan. New York: SUNY Press.

Schugurensky, D. (2002) Transformative Learning and Transformative Politics: the pedagogical dimension of participatory democracy and social action, in E. O’Sullivan., A. Morrell \& M.A. O'Connor (Eds) Expanding the Boundaries of Transformative Learning: essays on theory and praxis, 59-76. New York \& Basingstoke: Palgrave.

Simeone, D. (1996) Verso la Scuola di Barbiana. L'esperienza pastorale educativa di don Lorenzo Milani a S. Donato di Calenzano. San Pietro in Cariano (Verona): Il Segno dei Gabrielli Editori.

Stédile, J.P. \& Fernandes, B.M. (2001) Brava Gente. La Lunga Marcia del Movimento Senza Terra del Brasile dal 1984 al 2000. Rome: Rete Radié Resch.

Sultana, R.G. (2003) Guidance Policies in the Knowledge Society: trends, challenges and responses across Europe. Thessalnoniki: CEDEFOP.

Telleri, F. (2003) Educarsi per Educare. Teorie e Prassi. Sassari: Carlo Delfino Editore.

Thompson, J.L. (1983) Learning Liberation - women's response to men's education. London: Croom Helm.

Thompson, J.L. (1988) Adult Education and the Women's Movement, in T. Lovett (Ed.) Radical Approaches to Adult Education - a reader. London: Routledge.

Torres, C.A. (1987) Towards a Political Sociology of Adult Education: an agenda for research on adult education policy making. Occasional paper series, Centre for International Educational Development, University of Alberta, Edmonton, Canada. 
Verger, A. \& Bonal, X. (2006) Against GATS: the sense of a global struggle, Journal for Critical Education Policy Studies, 4(1). http:/ / www.jceps.com/?pageID=article\&articleID=55.

Wain, K. (2004) Lifelong Learning: some critical reflections, in D. Caruana \& P. Mayo (Eds) Perspectives on Lifelong Learning in the Mediterranean. Bonn: IIZ-DVV.

Walters, S. (Ed.) (1997) Globalization, Adult Education and Training: impacts \& issues. London: Zed Books.

Walters, S., Borg, C., Mayo, P. \& Foley, G. (2004) Economics, Politics and Adult Education, in G. Foley (Ed.) Dimensions of Adult Learning: adult education and training in a global era. Sydney: Allen \& Unwin.

Welton, M. (1993) Social Revolutionary Learning: the new social movements as learning sites, Adult Education Quarterly, 43(3), 152-164. http:/ / dx.doi.org/10.1177/0741713693043003002

Yarnit, M. (1980) The 150 Hours: Italy's experiment in mass working class adult education, in J. Thompson (Ed.) Adult Education for a Change. London: Hutchinson.

CARMEL BORG is Associate Professor and former Dean of the Faculty of Education at the University of Malta and his research/teaching interests include curriculum studies, critical pedagogy, adult education and higher education. Correspondence: Carmel Borg, University of Malta, Msida MSD 2080, Malta (carmel.borg@um.edu.mt).

PETER MAYO is Professor and Coordinator of the Adult Education Programme at the Faculty of Education, University of Malta. His research/teaching interests include sociology of education, social theory, adult education, international education and critical pedagogy. Correspondence: Peter Mayo, University of Malta, Msida MSD 2080, Malta (peter.mayo@um.edu.mt). 